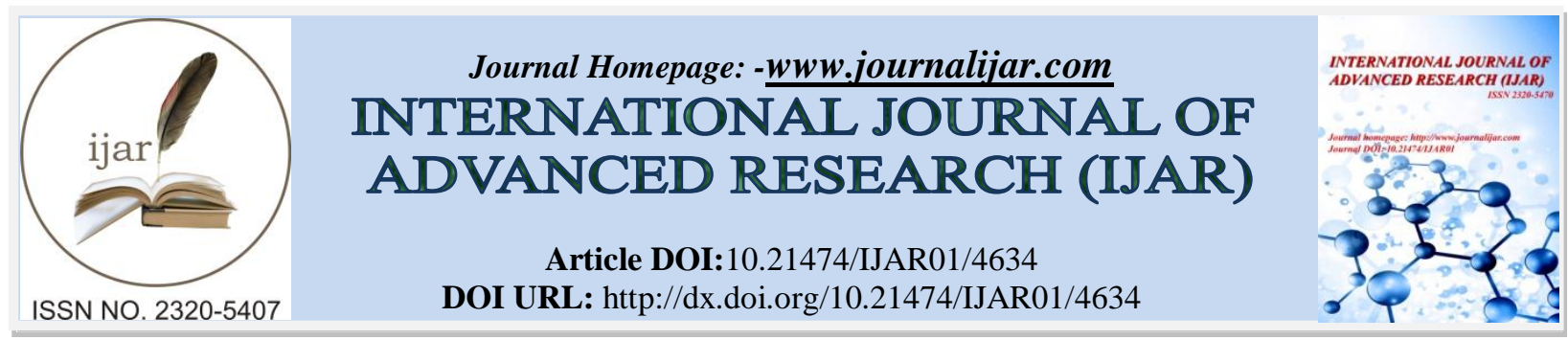

RESEARCH ARTICLE

\title{
IMPACT OF SUPPLY CHAIN MANAGEMENT PRACTICES ON PRODUCT QUALITY IN INDIAN HANDLOOM INDUSTRY WITH REFERENCE TO MASTER WEAVERS.
}

\author{
Dr.Kalyani Anumala ${ }^{1}$ and Nagaraj Samala ${ }^{2}$. \\ 1. C-169, HAL Colony, HAL Post, Balanagar, Hyderabad, India. \\ 2. Research Scholar, School of Management Studies, University of Hyderabad, Hyderabad, India.
}

\section{Manuscript Info}

Manuscript History

Received: 27 April 2017

Final Accepted: 29 May 2017

Published: June 2017

Key words:-

Supply Chain Management Issue,

Handloom Industry, Master Weaver,

Handloom Product Quality

\begin{abstract}
In the last 100 years, the handloom industry one of the ancient industries of India has faced a lot of changes in the form of mechanization, fibers used, refined methods of manufacturing and designing etc. (Rajeswari, 2017). In the current scenario, the handloom sector has lost its potential for competition when compared with other sectors, especially in terms of market share, and has become almost illusory in most of the countries. Keeping this in view the study aims to understand the issues of supply chain management practices involving master weavers in handloom industry and the impact of supply chain management practices on product quality. This study adopted quantitative methodology, where 365 master weavers were selected through purposive sampling technique. The study findings reveal that the handloom industry is unorganized. This reflects that there is a supply chain management issue which in turn impacts product quality.
\end{abstract}

Copy Right, IJAR, 2017,. All rights reserved.

\section{Introduction:-}

In the last 100 years, the handloom industry one of the ancient industries of India has faced a lot of changes in the form of mechanization, fibers used, refined methods of manufacturing and designing etc. (Rajeswari, 2017). The textile industry occupies a vital place in the Indian economy and contributes substantially to its export earnings. Textile exports represent nearly 30 per cent of the country's total exports. It has a high weightage of over 20 per cent in the national production. It provides direct employment to over 15 million persons in the mill, power loom and handloom sectors (Nema et al., 2013).

The structure of the Indian textile and garment industry is full of variability having the players at every level of their supply chain with lot of structural, operational and performance differences (Giri and Shankar Rai, 2013). The supply chain consists of all the activities associated with the flow and transformation of goods from the raw material stage, through to the end user, as well as the associated information flow.

In the current scenario, the handloom sector has lost its potential for competition when compared with other sectors, especially in terms of market share, and has become almost illusory in most of the countries. On the contrary, there are many Asian countries, such as India, Srilanka, Cambodia, Thailand, and Bangladesh, which are even today the pioneers in handloom sectors and are still continuing to maintain its pride as employment providers to huge populations, particularly in rural areas. India can enhance its status and register a huge footprint in global market 
place, by giving proper importance to this down falling industry and by supplying the Indian made handloom articles globally.

Supply chain management (SCM) involves the key processes such as planning, implementing and controlling, the activities (such as sourcing, procurement, conversion, and logistics management) of the supply chain for satisfying the requirements of the customers very efficiently. It is very important to note that the SCM also encompasses coordination and collaboration with channel partners such as suppliers, third-party service providers, intermediaries and importantly, customers. The success of SCM can be achieved by receiving a change from managing individual activities to integrating activities for key supply chain processes. (Rajeswari, 2016).

However, the SCM process involved in handloom sector is haphazard, i.e. there is lack of adequate mechanism to procure the raw product and produce them, then to sell the end products to the consumer. Given this backdrop, the study aims to analyze the supply chain management practices in Indian handloom industry. Moreover, the purpose of the study is to assess the supply chain scenario and issues present in this industry in certain districts of undivided state of Andhra Pradesh.

\section{Literature Review:-}

Overview of Indian Handlooms:-

Of all the arts and crafts in India, hand-woven textiles are probably the oldest and most widely recognized. Providing direct and indirect employment to more than 3 million weavers, handloom industry is the second largest economic activity in India. Handlooms contribute to nearly $23 \%$ of cloth production and it plays a major role in Indian economy in view of its significant contribution to GDP. However, with the increasing onslaught of changes in fashion, the handloom sector has been suffering significantly in terms of technology, productivity and accessibility to market. Since 1960 and up to 95, the share of handloom production in the total textile production remained more or less constant at about 23\%. However after 1995, it started declining and is pegged at 13\% during 2004-05. The tradition of handlooms is so strong that the entire country is dotted with places famous for some or the other handloom product (Nayak et al., 2008).

\section{Handloom Industry in Undivided State of Andhra Pradesh:-}

Handloom sector plays an important role in state economy. Weaving is the basic process among the various manufacturing stages of handloom products. Andhra Pradesh is known as one among the predominant regions involved in handloom and weaving in the Indian sub-continent. There are more than 2 lakh handloom weavers in the cooperative fold and more than 1 lakh weavers outside the cooperative fold. APCO is the apex society that deals with the marketing of handloom products. Most of the looms located in the state are found in the rural regions wherein the business is merged with rural people as a primary household activity. Men weave whereas women and children involve themselves in the preparation processes of weaving. Weaving is a tradition in the state of Andhra Pradesh; however the industry is shrinking its size and the glory of weavers is fading these days (Muneendra and Prakash, 2016).

There have been crisis in the availability of raw materials, especially yarn, are one such factor. Further, the phenomenal increase in yarn prices has been a major blow to handloom weavers. Therefore, the position of master weavers was strengthened during a severe drought during 1957-62. It has been observed that majority of the weavers work for master weavers, most in their own houses, but there are various weaving sheds with appalling conditions (Niranjana and Vinayan, 2001). There are issues facing by the handloom industry in this area are in terms of high cost of energy, low level of automation, absence of technical business development service providers, inadequate manpower, lack of standard quality measures, and high input costs. In addition, there are problems in availing bank credit and low level of enterprise social responsibility. This indicates various issues at each level of supply chain management (Micro Small and Medium Enterprises, n.d.).

The problems faced by the Handloom Weavers Co-operative Societies are inadequate activation of looms, political interference, high production cost, lack of adequate marketing facilities, improper implementation of development schemes, misuse of funds and heavy dues from the Apex Society (APCO). Another study in this regard revealed the lapses of the Government in respect of non-compliance of the rule of hank yarn to be produced by the spinning mills and the supply of yarn by the NHDC. This was the major reason for most of the weavers and master weavers to buy the required yarn from the mills. Moreover, there is no adequate mechanism on the regulation of prices of yarn, dyes and other chemicals (Chalam, 2001). All these concerns indicate about supply chain management issues being faced by the master weavers. 


\section{Overview of Supply Chain Management Issues in General:-}

With the manufacturing operations globalized, the need is to have a global procurement network in place to meet the requirements of supply chain. As per the views cited by chief procurement officers, the challenge is in selecting a strategic supplier that would ensure to provide quality service to manufacturing locations matching global standard. Reason could be attributed to the fact that manufacturers have the responsibility to produce high-quality products (Bossard, 2016). Moreover, among the various challenges being faced in supply chain, there is relevance of monetization, volatile nature of market, economic contractions, and recovery cycles matter in the aspects of distribution, invoicing, manufacturing, and materials sourcing. In addition, there are issues of getting expanded into new markets, dealing with complex taxation procedure, invoicing and localization burdens. Therefore, with these inevitable critical functions, enterprises must find a path to optimize supply chains to attain competitive edge over others (Swartz, 2017).

Broadly, the flow of supply chain management could be categorized as production flow, information flow, and finances flow. The product flow includes the movement of textiles from a supplier to a customer, as well as any customer returns or service needs. The information flow involves transmitting orders and updating the status of delivery. The financial flow consists of credit terms, payment schedules, and consignment arrangements (Basu \& Sharma, 2011).

\section{Supply Chain Management Practices in Indian Handloom Industry:-}

Textile Industry of India is one of the leading textile industries in the world. The Indian textile industry needs efficient supply chain management. One area that needs more emphasis for global competitiveness of the entire supply chain is the interface between textiles and clothing. A shift is taking place from the traditional textile supply chain to garment supply chain. The study discusses the changing trends in the textile supply chain in India and the need for an interface between textile and clothing for efficient supply chain management in textile industry.

India is one of the few countries that own the complete supply chain in close proximity from diverse fibers to a large market. It is capable of delivering packaged products to customers comprising a variety of fibers, diverse count sizes, cloths of different weight and weave, and panoply of finishes. This permits the supply chain to mix and match variety in different segments to deliver new products and applications.

However, Indian textile industry has suffered in the past from low productivity at both ends of the supply chain, i.e. low farm yields affecting cotton production and inefficiency in garment sector due to restriction of size and reservation. Added to this, contamination of cotton with consequent increase in cost, poor ginning, high average defect rates in production process, hank yarn requirement, etc. and its competitiveness gets compromised severely (Chandra, 2005).

Access to raw material such as yarn, dyes and dye stuffs has become a problem. Since this is a rural and semi-rural production activity, weavers have to go far to get these raw materials (Reddy, n.d.). Moreover, the Indian textile and clothing industries have one of the longest and extremely fragmented supply chains in the world, with existence of many intermediaries between the producer and the final consumer. Each intermediary not only leads to lengthening of lead times, but also adds to costs. By the time the product reaches the final consumer, price of it increases manifold. Therefore, the need is to rationalize costs at each stage in the entire supply chain. Coordination between industry and relevant trade bodies needs to be improved to make the supply chain more efficient (Bedi, 2009).

\section{Supply chain management issue from the perspective of master weavers:-}

In Andhra Pradesh, handloom weaving which was once known for providing live hood to the rural poor is now has reached the deteriorating stage. There are certain factors related to supply chain management issues from the perspective of weavers. The handloom is one industry where it was known for its versatile nature and innovation in developing the products. However, in the present context of globalization and rapid technological developments, handloom sector has set of issues especially in supply chain management in terms of procurement of yarn, production and distribution. The major problems related to procurement of yarn are in poor quality, not available on time, and required count of yarn not available. The reason for these constraints is that the handloom weavers are not from the one area and transportation of yarn from one place to another consumes time. In addition, there is an issue of getting financial assistance to procure. The weavers even face many constraints during the production process such as lack of upgraded looms, lack of insights on innovative designs, and unaware about the latest trend in the market. Master weavers need to make themselves sustainable and viable in the market. On the contrary, the weavers 
are making age-old pattern of these products with no changes in their designs and patterns. As a result, the finishing and the designs of the products that reach to the market might not garner the attention of customers. Therefore, marketing the products is also one of the prominent issues of master weavers they have been grappling with (Goswami and Jain, 2011). There are a few studies conducted in the past that have been reviewed as in the following:

Sanil, Ramakrishnan, Alwethainani, Kazi, and Siddique (2016) conducted a study on the apparel companies based in India to determine the SCM techniques applied in these businesses. This study applied a questionnaire for collecting data. Based on the findings it can be concluded that the apparel companies obtained a number of advantages out of SCM application with reference to the efficacy and responsiveness in delivering the goods or services to the customers.

Kumar (2010) conducted a study to analyze production and marketing of handloom fabrics, which was conducted in Prakasam district of Andhra Pradesh. Again, this study made attempt to analyze the problems, progress, production, marketing aspect, and the technology used in handloom industry. The study concludes that handloom industry is having numerous problems in terms of technology, inadequate working capital, raw materials, production, pre-loom process, marketing, competition, and related problems which sometimes compel the wavers to commit suicides.

All these studies indicate about the supply chain issues in various kinds. Supply chain of cotton plays an important role in deciding the price behavior of fabrics in the textile market. The entire value chain of cotton, which starts from harvesting at field level ends with marketing of garments (Dalei et al., 2015). SCM is an interdisciplinary field that emphasizes cross-functional links and seeks to manage those links to enhance a firm's competitive advantage. It involves forecasting, resource allocation, production planning, flow and process management, inventory management, customer delivery, after-sales support and service, and a multitude of other activities and processes familiar and essential to business (Hussain et al., 2009).

However, in general, the supply chain is one case which reduces the efficiency of product supply and increases the cost. Handloom logistic is not managed in scientific way, where calculation of stock keeping period and cost incurred because of maintaining huge stock; money blocked for this purpose and interest burden on overall sector should be done. Orders for raw yarn are placed on past experience instead of using proper forecasting techniques and tool for optimizing the resources (Narzary, 2013)

\section{Study Objectives:-}

* To study the handloom industry in selective districts of undivided state of Andhra Pradesh

* To analyze supply chain management practices followed in undivided state of Andhra Pradesh with respect to master weavers

* To find out the impact of supply chain management practices on product quality

\section{Hypothesis:-}

H1: There is significant impact of supply chain management practices on product quality.

\section{Significance of the Study:-}

The handloom industry is having issues in terms of availing raw materials in the production stage to marketing the end products. In view of this, the need is to undertake a study of supply chain management practices in Indian handloom industry especially in a few districts of undivided state of Andhra Pradesh.

\section{Sampling:-}

This study implemented quantitative methodology. The data was collected from 365 respondents in various age groups of 25-65 by using purposive sampling technique. The decision over sample size was taken as per the factors such as nature of study, degree of accuracy sought for, and availability of sources (Miller, 1989). As per the study by Kavale, Mathur, Forness, Rutherford, and Quinn (1997), respondents were selected in accordance with the study objectives. The respondents were met personally to collect the data.

\section{Research approach:-}

This study implemented quantitative methodology by resorting to primary data collection method. The instrument implemented for collecting primary data was questionnaire. In this regard, data were collected through survey 
methods, where respondents filled the questionnaire related to the areas of supply chain management issues. A questionnaire was developed comprising of simple, rigid, open-ended and close-ended questions. Both open and closed ended questionnaire are included in the survey questionnaire.

Additionally, Likert scale was also implemented in the questionnaire to enable the participants to explicit their views, which begins with strongly agree and ends with strongly disagree (Dundas, 2008). The questionnaire consisted of questions developed from reviewing the relevant literature on this research area.

\section{Data Analysis:-}

The present study results were analyzed through SPSS 20.0 version software. Using SPSS, Reliability analysis was carried out to find the consistency of the questionnaire and factor analysis to find the number of factors reduced from the items. AMOS 18 is used for the structural equation modeling (SEM) (Arbuckle, 2006). One of the main strengths of SEM is its accountability for measurement error when a latent variable of interest is represented by multiple manifest variables. Measures of fit that is, of the extent to which the implied variance-covariance matrix, based on the parameter estimates, reflects the observed sample variance-covariance matrix can be used to determine whether the hypothesized model gives an acceptable representation of the analyzed data.

Table 1:- Demographic Characteristics of Master Weavers $(n=365)$

\begin{tabular}{|c|c|c|}
\hline Demographics & Frequency $(n)$ & Percent (\%) \\
\hline \multicolumn{3}{|l|}{ Gender } \\
\hline Male & 365 & 100 \\
\hline \multicolumn{3}{|l|}{ Social Class / Caste } \\
\hline $\mathrm{BC}$ & 365 & 100 \\
\hline \multicolumn{3}{|l|}{ Sub Caste } \\
\hline Padmashali & 311 & 85.2 \\
\hline Devanga & 54 & 14.8 \\
\hline \multicolumn{3}{|l|}{ Religion } \\
\hline Hindu & 365 & 100 \\
\hline \multicolumn{3}{|l|}{ Society member } \\
\hline Yes & 194 & 53.2 \\
\hline No & 171 & 46.8 \\
\hline \multicolumn{3}{|l|}{ Weaver Identity Card } \\
\hline Yes & 187 & 51.2 \\
\hline No & 178 & 48.8 \\
\hline \multicolumn{3}{|l|}{ Age (in years) } \\
\hline $25-34$ & 27 & 7.4 \\
\hline $35-44$ & 165 & 45.2 \\
\hline $45-54$ & 127 & 34.8 \\
\hline $55-64$ & 43 & 11.8 \\
\hline$>=65$ & 3 & 0.8 \\
\hline \multicolumn{3}{|c|}{ Work Experience (in years) } \\
\hline $4-13$ & 106 & 29.0 \\
\hline $14-23$ & 177 & 48.5 \\
\hline $24-33$ & 57 & 15.6 \\
\hline $34-43$ & 19 & 5.2 \\
\hline $44-53$ & 5 & 1.4 \\
\hline $54-63$ & 1 & 0.3 \\
\hline \multicolumn{3}{|c|}{ Educational Qualification } \\
\hline Professional Course & 2 & 0.5 \\
\hline PG & 1 & 0.3 \\
\hline Graduation & 17 & 4.7 \\
\hline Intermediate & 24 & 6.6 \\
\hline SSC & 77 & 21.1 \\
\hline Below SSC & 209 & 57.3 \\
\hline
\end{tabular}




\begin{tabular}{|c|c|c|}
\hline Illiterate & 35 & 9.6 \\
\hline \multicolumn{3}{|c|}{ Number of looms being operated } \\
\hline $1-20$ & 260 & 71.2 \\
\hline $21-40$ & 75 & 20.5 \\
\hline $41-60$ & 28 & 7.7 \\
\hline $61-80$ & 0 & 0 \\
\hline $81-100$ & 2 & 0.5 \\
\hline \multicolumn{3}{|l|}{ Annual Turnover } \\
\hline $30000-1000000$ & 283 & 77.5 \\
\hline $1000001-2000000$ & 59 & 16.2 \\
\hline $2000001-3000000$ & 11 & 3.0 \\
\hline $3000001-4000000$ & 9 & 2.5 \\
\hline Above 4000000 & 3 & 0.8 \\
\hline
\end{tabular}

Table 1 shows the frequency analysis for demographical aspects of respondents. In this study, all the respondents are male with BC caste and Hindu religion. When considered the society member 53 per cent are a member of society and 51 percent with weaver identity card. When considered the age groups of respondents, most of the respondents $(45 \%)$ belonged to 35-44 years followed by, 35 percent were 45-54 years age group, 12 percent were 5564 years, 7 percent were 25-34 years and only 1 percent were equal and above 65 years age group. When considered the respondents' educational qualification, most of the respondents (57\%) were below SSC which is followed by, 21 percent were SSC, and 10 percent were illiterate, and so on. When a number of looms being operated are considered, most of the respondents $(71 \%)$ were operated in 1-20 looms. When considered the annual turnover, majority of the respondents (78\%) with 30000-1000000.

Table 2:- Reliability analysis $(\mathrm{n}=365)$

\begin{tabular}{|c|c|c|c|c|c|c|c|}
\hline Factors & $\begin{array}{l}\text { No. } \\
\text { of } \\
\text { Items }\end{array}$ & $\begin{array}{l}\text { Percentage } \\
\text { of } \\
\text { variation }\end{array}$ & Mean & $\mathrm{SD}^{*}$ & $\begin{array}{l}\text { Range } \\
\text { (Max-Min) }\end{array}$ & $\begin{array}{l}\text { Cronbach's } \\
\text { alpha }\end{array}$ & $\begin{array}{l}\text { Eigen } \\
\text { value }\end{array}$ \\
\hline \multicolumn{8}{|c|}{ Supply Chain Management Practices } \\
\hline $\begin{array}{l}\text { Strategic } \quad \text { Supplier } \quad \text { Partnership } \\
\text { (SSP) }\end{array}$ & 6 & 20.48 & 3.39 & 0.74 & $\begin{array}{l}4.00 \quad(5.00- \\
1.00)\end{array}$ & 0.902 & 4.30 \\
\hline Information Sharing (IS) & 6 & 17.72 & 3.51 & 0.66 & $\begin{array}{ll}4.00 & (5.00- \\
1.00) & \end{array}$ & 0.873 & 3.72 \\
\hline Customer Relationships (CR) & 5 & 14.73 & 4.84 & 0.35 & $\begin{array}{l}1.60 \quad(5.00- \\
3.40)\end{array}$ & 0.825 & 3.09 \\
\hline Information Quality (IQ) & 4 & 11.95 & 3.48 & 0.72 & $\begin{array}{l}3.50 \quad(4.75- \\
1.25)\end{array}$ & 0.819 & 2.51 \\
\hline
\end{tabular}

*Standard Deviation, Max- Maximum, Min- Minimum

Table 2 presents the findings of supply chain management practices of Indian handloom industry. The Cronbach's alpha for each construct ranges from 0.819 to 0.902 . Therefore, the refined measurement scale was considered to possess high internal consistency and reliability among the items.

The twenty-one items are taken into a factor analysis. The total twenty-one questions are reduced into four factors. The four factors are Strategic Supplier Partnership, Customer Relationships, Information Sharing and Information Quality (Li et al., 2006; Lotfi et al., 2013) Six items with inputs from employee were loaded under Factor one with loading ranging from 0.836 to 0.802 . Hence, it was named as "Strategic Supplier Partnership". Six items were loaded under Factor Two with loading ranging from 0.832 to 0.693 and named as "Information Sharing". Five items were loaded under Factor Three with ranging from 0.876 to 0.502 and named as "Customer Relationship". Four items are loaded under Factor Four with ranging from 0.886 to 0.750 . These items are under "Information Quality".

Table 3:- Reliability and validity estimates for supply chain management practices $(\mathrm{n}=365)$

\begin{tabular}{|l|l|l|l|}
\hline Factors & $\begin{array}{l}\text { Composite Reliability } \\
(\mathrm{CR}>0.7)\end{array}$ & $\begin{array}{l}\text { Average Variance } \\
\text { Extracted (AVE > 0.5 ) }\end{array}$ & $\begin{array}{l}\text { R-Square } \\
(\mathrm{R} 2)\end{array}$ \\
\hline $\mathrm{CR}$ & 0.886 & 0.617 & 0.234 \\
\hline
\end{tabular}




\begin{tabular}{|l|l|l|l|}
\hline IQ & 0.873 & 0.633 & \\
\hline IS & 0.906 & 0.616 & \\
\hline PQ & 0.827 & 0.408 & \\
\hline SSP & 0.924 & 0.670 & \\
\hline
\end{tabular}

Convergent validity is the degree to which multiple methods of measuring a variable provide the same results (O’Leary-Kelly and Vokurka, 1998). Following criteria must be satisfied towards ensuring convergent validity: CR$>0.7, \mathrm{CR}>\mathrm{AVE}$ and AVE > 0.5 (Hair et al., 2010). Convergent validity can be established with the help of Construct Reliability (CR) and Average Variance Explained (AVE). AVE of four constructs for supply chain management practices were found to be greater than 0.5. Further, in the case of all four constructs, the CR (Alpha) statistic is significantly greater than their respective AVE statistic (Table 3). Thus, all four constructs satisfied all prerequisites of convergent validity.

It involves the assessment of the degree to which an operationalization correctly measures its targeted variables (O'Leary-Kelly and Vokurka, 1998). According to them, establishing construct validity involves the empirical assessment of unidimensionality, reliability, and validity (convergent and discriminant). To check unidimensionality, a measurement model was specified for each construct and CFA (Figure. 1) was run for all the constructs.

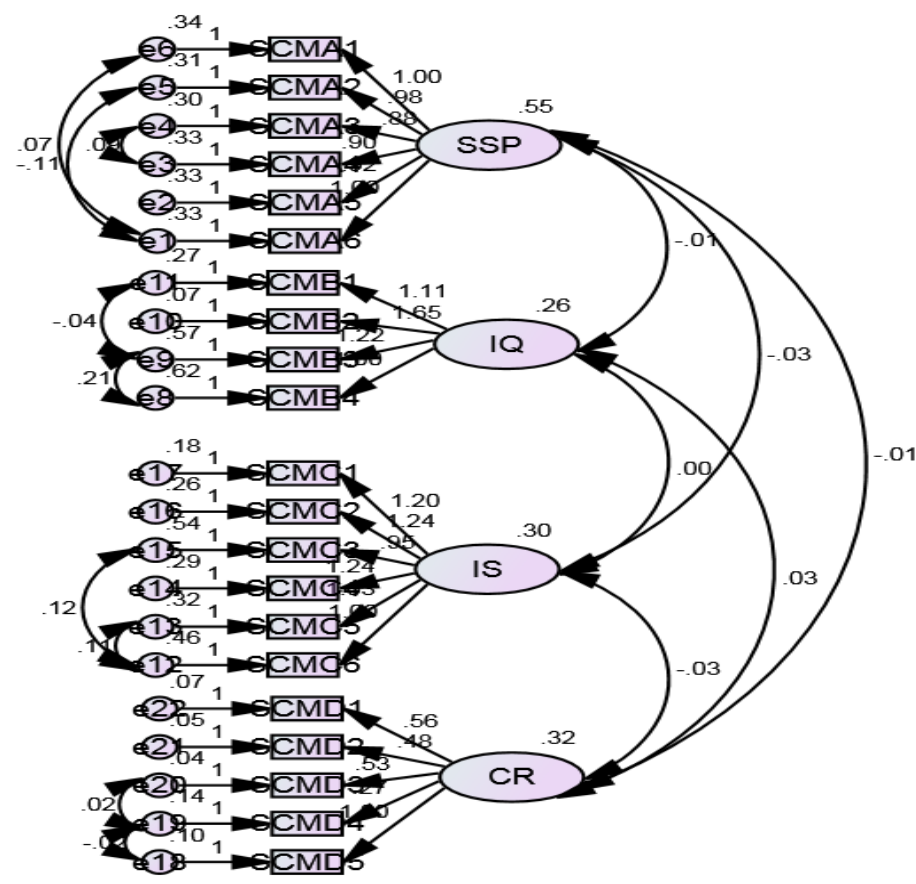

Fig 1:- CFA first order model for supply chain management practices

Individual items in the model were examined to see how closely they represent the same construct. A Comparative Fit Index (CFI) of 0.90 or above for the model implies the existence of strong evidence of unidimensionality (Byrne, 1994). The CFI values obtained for all the four constructs in the scale are equal to or above 0.90 .

Table 4:- Model fit indices for first order model constructs of supply chain management practices

\begin{tabular}{|l|l|l|}
\hline Indices & Recommended & Model Fit Indices \\
\hline GFI & $\geq 0.90$ & 0.939 \\
\hline CFI & $\geq 0.90$ & 0.980 \\
\hline CMIN/df & $<5$ & 1.430 \\
\hline AGFI & $\geq 0.90$ & 0.919 \\
\hline RMSEA & $\leq 0.08$ & 0.034 \\
\hline RMR & $\leq 0.08$ & 0.032 \\
\hline
\end{tabular}


Table 4 is indicating a strong evidence of unidimensionality for the scale. Upon satisfaction of unidimensionality and reliability parameters, the scale was further subjected to empirical validation analysis.

Table 5:- Model Fit Indices for full Order Model Constructs of Supply Chain Management Practices and Product Quality

\begin{tabular}{|l|l|l|}
\hline Indices & Recommended & Model Fit Indices \\
\hline GFI & $\geq 0.90$ & 0.933 \\
\hline CFI & $\geq 0.90$ & 0.974 \\
\hline CMIN/df & $<5$ & 1.525 \\
\hline AGFI & $\geq 0.90$ & 0.911 \\
\hline RMSEA & $\leq 0.08$ & 0.038 \\
\hline RMR & $\leq 0.08$ & 0.031 \\
\hline
\end{tabular}

Model fit is assessed on the basis of CMIN/df, P-value, Comparative Fit Index (CFI), Goodness of Fit Index (GFI), Adjusted Goodness of Fit Index (AGFI), Root Mean Square Error of Approximation (RMSEA) and P close. Model fit indices for supply chain management practices and product quality constructs were calculated, and the results have been indicated in Table 5 .

Upon satisfaction of reliability and validity of individual constructs as well as the overall supply chain management practices model (Figure 2); the study proceeded to determine the fitness of the overall measurement model based on model fit indices generated as a part of AMOS output.

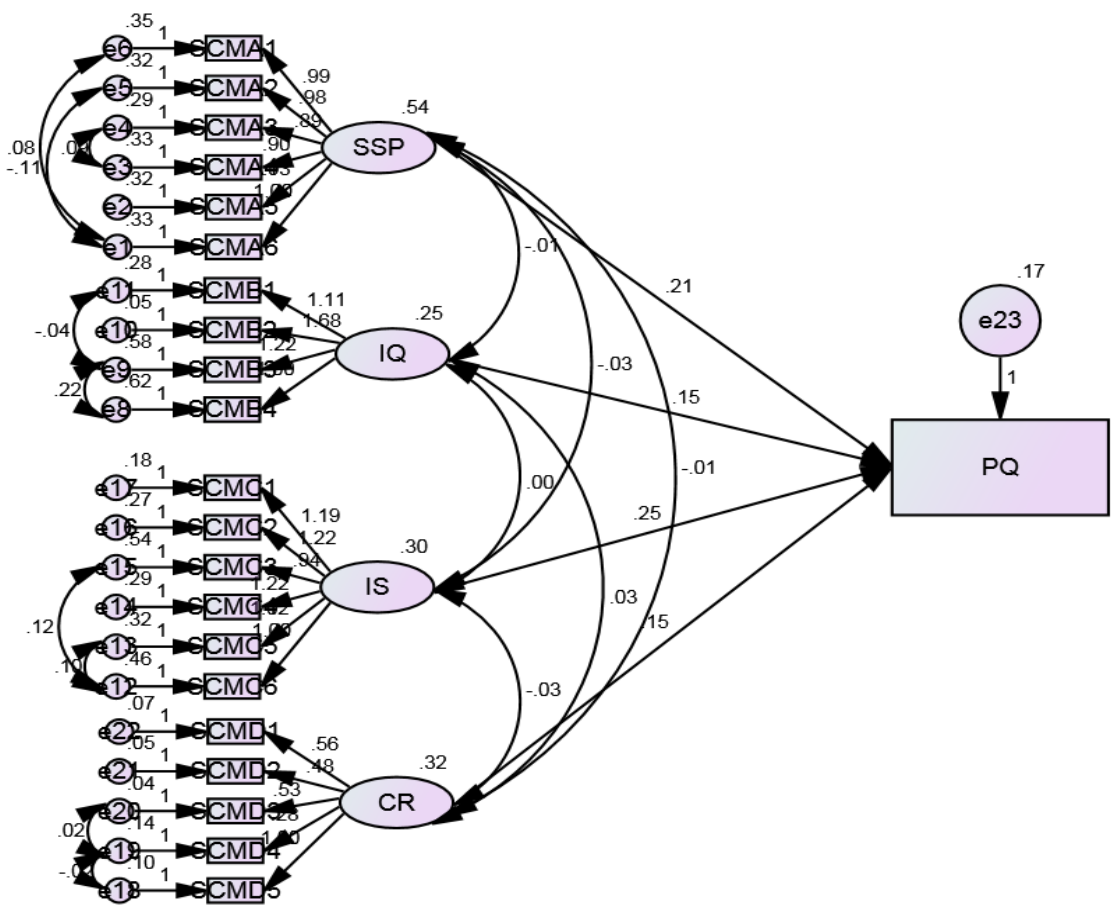

Fig 2:- Full order model for supply chain management practices and product quality

\section{Conclusion:-}

It could be concluded that handloom sector plays a significant role to the economy. However, the pressing issue is the inadequate supply chain management process. As a result, firms and individual weavers find it difficult in procuring the raw materials as well as in the process of product and finally selling those in the market. In addition, this sector is having issues in terms of obsolete technology, low productivity, availing working capital, and poor marketing links. Therefore, supply chain management practices needs to be adopted by the firms. Moreover, the players involved in this sector needs to rationalize costs at each stage of supply chain. Coordination between industry and relevant trade bodies also required to ensure a sound supply chain process in place. 
The scenario of supply chain management is no different in undivided state of Andhra Pradesh as well. There are certain districts like Nalgonda, Warrangal, Guntur, Krishna, Prakasam, and Hyderabad are known for weaving world class handlooms. However, the unorganized and decentralized nature of supply chain leads to less production, more time consumption. As a result, this sector is fading day by day for which the evolvement of power loom is another reason. The study result reflects that there are two variables (dependent and independent). Here supply chain management practice is independent variable and product quality as dependent variable. In addition, there are four significant factors such as Supplier Partnership, Customer Relationships, Information Sharing and Information Quality, which are significant predictor of product quality. Hence the hypothesis is accepted and is concluded that, there is an association between supply chain management practices and product quality.

\section{References:-}

1. Arbuckle, J. L. (2006): Amos (Version 7.0) [Computer Program]. Chicago: SPSS. Retrieved from http:/www.hsc.edu.kw/student/app_manuals/SPSS/Amos 7.0 User's Guide.pdf

2. Basu, B. and Sharma, A. (2011): Supply Chain Management in Textiles. Retrieved June 9, 2017, from http://www.indiantextilejournal.com/articles/FAdetails.asp?id=3940

3. Bedi, J. S. (2009): Assessing the Prospects for India's Textile and Clothing Sector. Retrieved from http://texmin.nic.in/sites/default/files/Report_NCAER_CITI_nmcc_20091001.pdf

4. Bossard. (2016): Supply Chain Management: challenges and solutions. Retrieved June 9, 2017, from https://www.bossard.com/en/how-we-add-value/key-challenges-in-supply-chain-management.aspx

5. Byrne, B. M. (1994): Structural Equation modeling with EQS and EQS/Windows-Basic Concepts, Applications and Programming. Thousand Oaks, CA: Sage Publications. Retrieved from https://books.google.co.in/books/about/Structural_Equation_Modeling_with_EQS_an.html?id=etUfAQAAIAA J\&redir_esc $=\mathrm{y}$

6. Chalam, G. V. (2001): Problems and Prospects of Handloom Industry in Co- operative Sector ñ A Study of Handloom Weaverís Co-operative Societies in Krishna District. Indian Co-Operative Review., 38(3): $137-142$.

7. Chandra, P. (2005): The Textile and Apparel Industry in India. (Basu K Ed.). India: Oxford University Press.

8. Cooper, D. R. and Schindler, P. S. (2003): Business Research Method (8th ed.). Boston: McGraw Hill Irwin.

9. Dalei, N. N. Gupta, A. and Dash, P. (2015): Supply chain management of cotton in Odisha: Small and medium farmer's concern. International Journal of Multidisciplinary Research and Development., 2(5): 328-335. Retrieved from https://www.researchgate.net/publication/301233442_Supply_chain_management_of_cotton_in_Odisha_Small and_medium_farmer's_concern

10. Discovered India. (2016): Handlooms In Andhra Pradesh. Retrieved June 9, 2017, from http://www.discoveredindia.com/andhra-pradesh/culture-in-andhra-pradesh/handlooms-in-andhra-pradesh/

11. Dundas, K. (2008): Work life balance: There is no "one-size fits all" solution. In Managing Matters (K O’Rourke, pp. 7-8). New South Wales.

12. Giri, S. and Shankar Rai, S. (2013): Dynamics of Garment Supply Chain. International Journal of Managing Value and Supply Chains., 4(4): 29-42. https://doi.org/10.5121/ijmvsc.2013.4403

13. Goswami, R. and Jain, R. (2011): An Analytical Study of Managerial Issues of Handloom Industry in Jaipur District. International Journal of Research in Commerce \& Management., 2(9): 94-98: Retrieved from file://C:/Users/1040/Downloads/ijrcm-1-vol-2_issue-9-art-17.pdf

14. Hair, J. F., Babin, B., Money, A. H. and Samouel, P. (2003): Essential of business research methods. United States of America: John Wiley \& Sons. Retrieved from https://books.google.co.in/books/about/Essentials_of_Business_Research_Methods.html?id=ybGpQgAACAAJ \&redir_esc=y

15. Hair, J. F., Black, W., Babin, B. and Anderson, R. E. (2010): Multivariate Data Analysis (7th ed.). Upper Saddle River, New Jersey: Hall. Retrieved from https://books.google.co.in/books/about/Multivariate_Data_Analysis.html?id=JlRaAAAAYAAJ

16. Hussain, D., Figueiredo, M. and Ferreira, F. (2009): SWOT Analysis of Pakistan Textile Supply Chain. $\begin{array}{llll}\text { Retrieved June } & 9, & 2017, & \text { from }\end{array}$ https://www.researchgate.net/publication/228447616_SWOT_Analysis_of_Pakistan_Textile_Supply_Chain

17. Jiyo. (2016): Nalgonda District.

18. Kavale, K. A., Mathur, S. R., Forness, R., Rutherford, R. B. and Quinn, M. M. (1997): Effectiveness of Social Skills Training for Students With Behavior Disorders: A Meta Analysis. In T. E. Scruggs \& M. A. Mastropieri (Eds.), Advances in learning and behavioral disabilities (pp. 1-28). New York: Elsevier.

19. Kumar, M. (2010): An Analysis of Production and Marketing of Handloom Fabrics in Andhra Pradesh- A study 
of Prakasham District. Nagarjuna University. Retrieved from http://shodhganga.inflibnet.ac.in/handle/10603/9841

20. Leedy, P. D. and Ormrod, J. (2001): Practical research: planning and design (7th ed.). Upper Saddle River, N.J: Prentice-HaIl Inc. from https://books.google.co.in/books?id=8vFDPgAACAAJ\&source=gbs_book_other_versions

21. Li, S., Ragu-Nathan, B., Ragu-Nathan, T. S. and Subba Rao, S. (2006): The impact of supply chain management practices on competitive advantage and organizational performance. Omega., 34(2):107-124. https://doi.org/10.1016/j.omega.2004.08.002

22. Lotfi, Z., Mukhtar, M., Sahran, S. and Zadeh, A. T. (2013): Information Sharing in Supply Chain Management. Procedia Technology, 11, 298-304. https://doi.org/10.1016/j.protcy.2013.12.194

23. Micro Small and Medium Enterprises. (n.d.): Brief Industrial Profile of Guntur District. Hyderabad: MSMEDevelopment Institute. Retrieved from http://dcmsme.gov.in/dips/guntur profile_ap.pdf

24. Miller, B. (1989):The Multigrade Classroom: A Resource Handbook for Small, Rural Schools. Portland: Northwest Regional Educational Laboratory. Retrieved from https://www.researchgate.net/publication/234568167_The_Multigrade_Classroom_A_Resource_Handbook_for _Small_Rural_Schools

25. Mukund, K.and Syamasundari, B. (2001): Traditional Industry in the New Market Economy - The Cotton Handlooms of Andhra Pradesh. New Delhi: Sage Publications, New Delhi.

26. Muneendra, N., Prakash, N.R.M., 2016. The Status of Handnloom Industry in Andhra Pradesh. Int. J. Res. IT Manag. 6, 69-73.

27. Nadh, R. R., Rao, P. V. and Vardhan, B. M. H. (2013): Handloom Market. Int. J. Emerg. Res. Manag. \&Technology., $2(5)$ : 6-11. $\quad$ Retrieved from https://www.ermt.net/docs/papers/Volume_2/issue_5_May2013/V2N5-108.pdf

28. Narzary, J. (2013): Marketing problems and prospects of handloom and handicrafts industry in B.T.A.D. Global Research Methodology Journal., 3(7): 1-8. Retrieved from http://www.grmgrlaranya.com/Journals/7th issue/Marketing problems and prospects of handloom and handicrafts industry in B.T.A.D..pdf

29. Nayak, P., Rout, T. , Samantray, P. and Dash, P. (2008): Khandua Sarees \& Fabrics: Tradition and Pride of Orissa. Mumbai: Textiles Committe.

30. Nema, N., Soni, S. R., Talankar, A. and Nougriaya, S. (2013): Green Supply Chain Management Practices in Textile and Apparel Industries: Literature Review. Int. J. Eng. Technol. Manag. Res., 1(1): 330-336. Retrieved from https://pdfs.semanticscholar.org/0cbc/7ea05653aa998eef64d901ab2b4f0ab22e80.pdf

31. Niranjana, S.and Vinayan, S. (2001): Report on Growth and Prospects of the Handloom Industry: Study Commissioned by the Planning Commission.

32. O'Leary-Kelly, S. W. and Vokurka, R. J. (1998): The empirical assessment of construct validity. J. Oper. Manag., 16(4): 387-405. Retrieved from http://www.sciencedirect.com/science/article/pii/S0272696398000205

33. Rajeswari, B. (2017): A Study on Impact of Supply Chain Prospects on the Performance of Handloom Sector. Retrieved June 9, 2017, from http://www.fibre2fashion.com/industry-article/4314/a-study-on-impact-of-supplychain?page $=1$

34. Reddy, D. N. (n.d.): Crisis in Handloom Sector: Critical Factors to be addressed. Chirala, India: Centre for Handloom Information and Policy Advocacy.

35. Sanil, H. S., Ramakrishnan, S., Alwethainani, M., Kazi, A. G. and Siddique, M. (2016): Effectiveness of Supply Chain Management with Reference to Apparel Industry: A Case Study in India. Int. Rev. Manag., 6(4S): 176184. Retrieved from https://econjournals.com/index.php/irmm/article/view/2484

36. Sreenivas, A. and Ismail, M. (2013): Problems Faced By Handloom Weavers in Telangana Sate-A Study of Karimnagar District.

37. Swartz, S. (2017): Challenges for Today's Global Supply Chain: Cost, Profitability and Personalization. Retrieved June 9, 2017, from http://www.inboundlogistics.com/cms/article/challenges-for-todays-globalsupply-chain-cost-profitability-and-personalization/ 